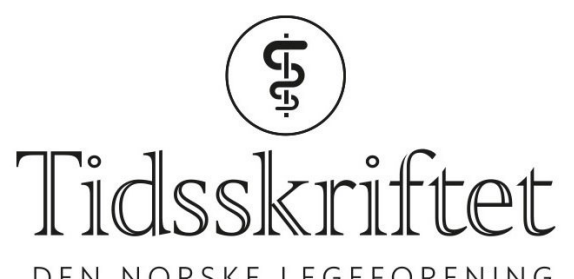

DEN NORSKE LEGEFORENING

\title{
Keiserens nye ord
}

LEGELIVET

\section{INGRID HOKSTAD}

E-post: ihokstad@gmail.com

Ingrid Hokstad er lege og stipendiat ved Revmatismesykehuset på Lillehammer.

Ordet doktor innga tidligere en viss ærefrykt og status, men nå florerer det av konkurrerende, lekre yrkestitler der ute. Trenger legestanden en omdømmestylist?

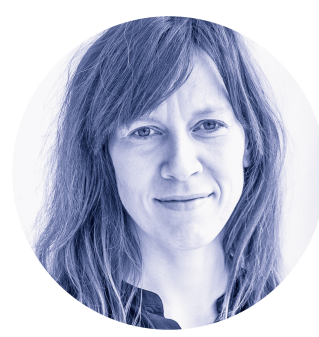

Har leger et imageproblem? Hvis man kikker rundt på jobbportalen LinkedIn, kan man begynne å lure. Andre yrkesgrupper smykker seg med avanserte, fasjonable yrkestitler, mens vi «bare» er leger (eventuelt $M D$ om vi ønsker å høres litt internasjonale ut). En venninne som nylig avsluttet en bachelor i økonomi, og som nå trakter kaffe og printer dokumenter i et konsulentfirma, betegner seg som Key Account Manager, hvilket unektelig høres imponerende og profesjonelt ut.

Det synes å ha gått inflasjon i engelske, til dels meningsløse og overdådige yrkestitler. En selger i klesbutikken gjenoppstår som kunderelasjonsleder, personvernombudet er plutselig blitt Data Protection Officer, og ledere er plutselig både CEO, COO, CFO og CSO (noen som vet forskjellen?). Språkrådet må faktisk på jevnlig basis assistere sjefer og ansatte med å oversette uforståelige titler (1).

Legenes titler har blitt endret flere ganger det siste århundret (2). Fra doktor til lege, deriblant turnuslege, assistentlege og overlege. Fra 2017 har vi fått LIS-begrepet for alle leger i spesialisering. Turnuslege har blitt LIS1, og siden det er for få LIS1-stillinger i forhold til antall søkere, har det også oppstått nye, uformelle stillingstitler som innkomstlege og LUS (lege uten turnus). I disse jobber nyutdannede leger - gjerne uten tilstrekkelig veiledning og opplæring - for å nå opp i kampen om å få starte spesialiseringsløpet sitt $(3,4)$.

I rekken av ikke spesielt pretensiøse titler vi leger omtales med, er dommen i Høyesterett om at leger i spesialisering er å anse som praksisarbeidere uten rett til fast ansettelse (5). Der har du en tittel som garanterer at du ikke blir headhuntet om du legger den til på CV-en i alle fall!

Mens legetittelen, og kanskje spesielt ordet doktor tidligere innga status og respekt, opplever mange nå at legenes autonomi svekkes. Tidligere redaktør av yngreleger.no, Trude 
Basso, fastslo i et intervju med Tidsskriftet i fjor at «vi er blitt arbeidstakere - vi har ikke den maktposisjonen vi hadde tidligere» (6). Kanskje ville vi lettere ha fått gjennomslag $i$ kampen for bedre arbeidsvilkår om vi hadde prangende, aktverdige titler?

Man trenger bare å kombinere ord som chief, executive, head, senior, president og key i en passe diffus miks og vipps: et nytt statussymbol på adgangskortet - eller en respektabel undertittel på gravsteinen når den tid kommer. LIS1 kan bli til Chief Emergency Room Vassal, og LIS2 kan gjenoppstå som Lead Epicrisis Executive Manager. Fastleger burde tituleres med en tittel som viser at de bærer resten av helsevesenet på sine skuldre. Kanskje et navn som Executive Handler, Concierge $\&$ Coordinator of Extensive Health Services kunne yte dem rettferdighet? Overlege heter i dag Senior Consultant på engelsk, men med så mye ansvar og erfaring er det på sin plass å utvide tittelen til noe mer høytsvevende som Key ChiefMedical Senior President.

Ord har betydning. På samme måte som de enkelte nukleinsyrene A, T, C og G kan gi opphav til all verdens fantastiske skapninger når de kombineres til DNA, kan bokstaver danne ord og setninger som berører oss, informerer og påvirker atferd. Ord kan såre og motivere, bygge tillit eller gi makt. Ord danner grunnlag for identitet. Hvordan vi beskriver karakteristika som legning, kjønn, yrke og livssyn, har betydning for hvordan vi selv og andre forstår og ser oss. En yrkestittel er altså ikke «bare ord». Jeg leste nylig om indere som heller ville ha en fin yrkestittel enn lønnsforhøyelse, fordi det økte sjansen for å lykkes på ekteskapsmarkedet. En tittel kan vise ansvarsområde og myndighet, inngi tillit og etablere kredibilitet.

Heldigvis er ikke pompøse titler det vi trenger for å gjøre en god jobb. Begrep som overlege er selvfølgelig ikke bare ord. Benevnelsen rommer både erfaring, kunnskap, slit og tårer. Det samme kan man si om både LIS og LUS. Jålete tittel eller ei - jeg er stolt av å være lege. La oss fortsette å være en yrkesgruppe som setter faget og pasienten i sentrum, som fokuserer på innhold fremfor staffasje. Vi vinner kanskje ikke konkurransen om den mest prangende tittelen på visittkortet, men det er helt ok så lenge vi bedrer livet til pasientene våre.

\section{LITTERATUR:}

1. Braathen F. Trenger hjelp til å forstå egne titler. Aftenposten 2.3.2011.

https://www.aftenposten.no/norge/i/Lnp7p/Trenger-hjelp-til-a-forsta-egne-titler (2.3.2011).

2. Hem E. Erlend Hem svarar. Tidsskr Nor Legeforen 2016; 136: 1744. [PubMed][CrossRef]

3. Bredeveien JM. Diagnose: utestengt. Dagsavisen 23.12.2018.

https://www.dagsavisen.no/helg-nye-inntrykk/reportasjer/diagnose-utestengt-1.1252272 (23.12.2018).

4. Fagbladet Journalen. Leger ansettes via Facebook.

https://fagbladetjournalen.no/leger-ansettes-via-facebook/ (4.10.2018).

5. Storvik AG. Høyesterett: LIS-leger er praksisarbeidere. Dagens Medisin 30.10.2013. https://www.dagensmedisin.no/artikler/2013/10/30/hoyesterett-lis-leger-er-praksisarbeidere/ (9.5.2015).

6. Svanstrøm C. Legens nye status presens. Tidsskr Nor Legeforen 2017; 137. doi:10.4045/tidsskr.17.0711. [PubMed][CrossRef]

Publisert: 15. februar 2019. Tidsskr Nor Legeforen. DOI: 10.4045/tidsskr.19.0013

(C) Tidsskrift for Den norske legeforening 2020. Lastet ned fra tidsskriftet.no 